\title{
Seeing Nichiren's Conception of the Lotus Sutra's Buddhism in his Kaimoku-shō
}

\author{
SEKIDo Gyōkai
}

\section{Introduction}

In the snow-covered Sammaidō Hall at Tsukahara (塚原三昧堂), on Sado Island, during the second month of the ninth year of the Bun'ei Period (1272), Nichiren 日蓮 (1222-82) wrote the Kaimoku-sho 開目抄. Having been exiled to Sado by the Kamakura shogunate in the tenth month of 1271, in order to teach his disciples and followers that the Lotus Sutra is the very teaching for the salvation of people in the Latter Age of Degenera-

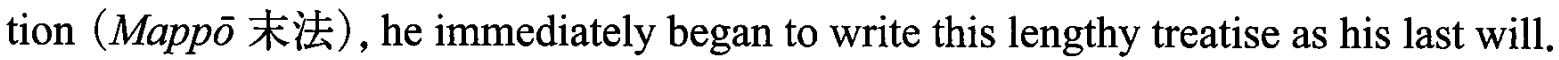

"Kaimoku" (opening of the eyes), signifies the purpose of the text: to exhort people to open their eyes widely in order that they might perceive the truth and grasp that the Lotus Sutra is the teaching for the salvation of those living in the Age of Mappō.

Nichiren wrote the Kaimoku-sho within a short period of time under difficult circumstances. As a result it has no organized table of contents. Based on later research by numerous scholars, it is seen as containing three major sections:

- Part I: Prologue (chapters 1-3), emphasizes that the essential nature of Buddhism, and the essential nature of the Lotus Sutra in particular, is at the core of spiritual cultures-including Confucianism and non-Buddhist doctrines.

- Part II: Main Discourse (chapters 4-16), maintains that the Lotus Sutra is a polished mirror that clearly reflects the predicted evil world of the Age of Mappō. The persecutions that Nichiren has personally experienced are the embodiment of the truth of what is foretold in the Lotus Sutra.

- Part III: Epilogue (chapters 17-18), discusses the dissemination of the Lotus Sutra's teaching in the future.

According to the structure of the Kaimoku-shō, I would like to show how Nichiren regards the Lotus Sutra. 


\section{Part I: Prologue (Chapters 1-3)}

\section{On the Chapter 1. Confucianism, Non-Buddhist Teachings, and Buddhism}

At the beginning of the Kaimoku-shō, Nichiren mentions three things that should be valued and respected, and three spiritual cultures that should be studied: All people should respect their leaders, their teachers, and their parents; and they should study Confucianism, non-Buddhist (gedō 外道) teachings, and Buddhism. ${ }^{1)}$

Nichiren first discusses the history and doctrines of Confucianism, and then he makes his objections to it. The sages of Confucianism know nothing of the past or the future. However, these sages, as such, cannot be helpful for the future lives of their rulers, teachers, and parents; and not knowing what they owe to them from the past, they cannot truly be considered as holy and wise. ${ }^{2)}$

Next, Nichiren states that there are ninety-five kinds of non-Buddhist schools, and, whether their doctrines are good or bad, none of them are able to surmount the obstacle of the suffering of the cycle of births and deaths. Those who follow good leaders would fall into evil realms after a few future lives, while those who follow lesser leaders are doubtlessly bound to plunge there forthwith in the next life. The most important thing for nonBuddhist teachings, and for Confucianism as well, is to become an entryway to Buddhism. ${ }^{3)}$

Third, Nichiren states that Śākyamuni Buddha is a magnificent leader (dōshi 導師) and the great eye (ganmoku 眼目) for living beings. Śăkyamuni is the great bridge (kyōryō 橋 梁) by which they can cross the river suffering and distress, the great captain (sensh $i$ 船 師) who guides people over the seas of hardship, and the fertile field (fukuden 福田) in which they plant the seeds of virtue. ${ }^{4)}$ Nichiren then declares that the Lotus Sutra is the highest peak within the range of the spiritual cultures of Confucianism, non-Buddhist teachings, and Buddhism, and that the Lotus Sutra is the true teaching of Śākyamuni Bud$\mathrm{dha},{ }^{5)}$ the founder of Buddhism. For forty years prior to the Lotus Sutra, Saakyamuni expounded sutras as numerous as the Ganges River's sands; however, they had not yet revealed the truth that he would reveal with the Lotus Sutra in his last eight years.

\section{On the Chapter 2. The Idea: "Three Thousand Realms Contained in One Thought"} (Ichinen sanzen 一念三千)

Nichiren points out that there are twenty important doctrines within the Lotus Sutra, and he emphasizes that "Attainment of Buddhahood by Those of the Two Vehicles" (Nijo sabutsu 二乗作仏) in chapter two, and “Attainment of Enlightenment in the Eternal Past" 
(Kuon jitsujō 久遠実成) in chapter sixteen, are especially important among them. ${ }^{6} \mathrm{He}$ criticizes the fact that the various Japanese schools didn't recognize this. He thought that "Ichinen sanzen" is the extremely symbolic philosophy of the Lotus Sutra, and that this philosophy is an undercurrent hidden within the text of the essential section (honmon 本 門) of the Lotus Sutra, ${ }^{7)}$ chapter sixteen.

\section{On the Chapter 3. Why Various Schools of Buddhism are Criticized}

Nichiren was critical of the various Japanese schools, that did not recognize how "Ichinen sanzen" was incorporated into their doctrines:

- Carefully reading the interpretations of the great teachers of Tiantai (Jp. Tendai) (Zhiyi 智顗, 538-597), the Tripitaka Master of the Faxiang (Jp. Hossō) School, Xuanzang 玄焋 (602-664), and his disciple, Grand Master Cien 慈恩 ( $\mathrm{Ji}$ 基, 632682 ), became aware of fallacies within their own views. While they did not go so far as to abandon their own schools, in their heart and mind they felt impressed by Tiantai.

- Tripitaka Masters of the Zheryan (Jp. Shingon) school, Śubhākarasiṃha (Ch. Shanwuwei, Jp. Zenmui 善無畏, 637-735), and Vajrabodhi (Ch. Jingangzhi, Jp. Kongōchi 金剛智, 671-741), established this Tiantai philosophy at the core of their own school, and added to it symbols (mudra, 印) and esoteric words (mantras, 真 言) to assert their own superiority.

- People do not realize that, during the time of Chengguan 澄観 (738-839), Tiantai philosophy was incorporated into the Huayan (Jp. Kegon) school and used to interpret the passage that reads, "Mind is like a skillful painter, reflecting everything," written in the Buddhāvatamsaka-nāma-mahāvaipulya-sūtra (Ch. Huayan jing, Jp. Kegon $\mathrm{Ky} \overline{\mathrm{o}}$ 華厳経). ${ }^{8)}$

\section{Part II: Main Discourse (Chapters 4-16)}

\section{On the Chapter 4. Attainment of Buddhahood by Those of the Two Vehicles}

Nichiren points out "Attainment of Buddhahood by Those of the Two Vehicles" in chapter two, and "Attainment of Enlightenment in the Eternal Past" in chapter sixteen as being extremely important doctrines of the Lotus Sutra, and that these are the main differences between the many sutras preached by the Buddha during the first forty years after his enlightenment and the Lotus Sutra. ${ }^{9)}$

He refers to many sutras that were expounded during the first forty years-sutras in 
which the attainment of Buddhahood by those of the two vehicles is rejected. ${ }^{10)}$ Nevertheless, Śăkyamuni Buddha suddenly countermands what these sutras expounded: in the Lotus Sutra, during the last eight years, he teaches that those in the two vehicles will attain Buddhahood. ${ }^{11)}$

\section{On the Chapter 5. Attaining Enlightenment in the Eternal Past}

Nichiren cites references from various sutras that teach that the historical Buddha attained Buddhahood under the pippala tree at Gayā. Furthermore, he indicates related points even from the Sutra of Infinite Meanings (Wuliangyi jing 無量義経) and chapter two of the Lotus Sutra as well. Nevertheless, in chapter sixteen of the Lotus Sutra it is revealed that Śākyamuni Buddha attained enlightenment in the eternal past. The Kaimoku-shō then indicates the extreme importance of the Lotus Sutra's doctrine of "Attaining Enlightenment in the eternal past" ${ }^{12)}$ : Because Śākyamuni Buddha's eternal aspect is made clear, the concept of "Ichinen sanzen" becomes real, too.

\section{On the Chapter 6. Assuming a Mindset of Resignation to Persecutions}

To speak ill of Śākyamuni Buddha's most supreme sutra, the Lotus Sutra, is a serious offense - the consequences of which will be to fall into unwholesome realms. In his criticisms of the doctrines of various schools of Japanese Buddhism, Nichiren was taking note of this. But he had faced a dilemma: If he were to proclaim even one word of this, government persecutions would most likely befall his parents, siblings, and teachers; but if he were not to speak out, he would become a person with no compassion who hides the truth that would save the people. He decided that he would advocate the teachings of the Lotus Sutra, the Nirvana Sutra, and other similar sutras. ${ }^{13)}$

\section{On the Chapter 7. Actual Experience of the Buddha's Predictions}

Nichiren endured and overcame great religious persecution four times. He professed his self-education regarding the Lotus Sutra as a declared practitioner of it. He said that, although his comprehension of the Lotus Sutra would not come to even one one-thousandth of that which Tiantai and Dengyō 伝教 (Saichō 最澄, 767-822) possessed, he dared to say that with regard to the tribulations he endured and his compassion for the people, he was beyond those masters. The Lotus Sutra predicts that its practitioners will be persecuted, ${ }^{14)}$ and he met with much persecution because he himself practiced in conformity with its teachings. ${ }^{15)}$ 


\section{On the Chapter 8. Why Aren't Guardian Divinities Protecting Devotees?}

Disciples and followers wonder why guardian divinities have not come to safeguard them. Nichiren himself wonders the same thing. Heavenly divinities made a vow to protect practitioners of the Lotus Sutra. He thought that they should quickly carry out the promise they made to Śākyamuni Buddha, but no help came. Did that mean that he is not a Lotus Sutra practitioner? This question, of cardinal importance in his life, is a starting point for several discussions in the Kaimoku-shō.

On the Chapter 9. "Ichinen sanzen" as Reflected in the Fourteen Chapters of the First Half (shakumon 迹門) of the Lotus Sutra

"Myō" 妙 is a word in the title of the Lotus sutra (Saddharma-pundarika-sütra, Ch. Miaofa lianhua jing, Jp. Myōhō renge kyō 妙法蓮華経). It has the meaning of "being fully complete (gusoku 具足) in the perfect teaching." It brings together all of the practices collectively designated as the "six pāramitās" (rokuharamitsu 六波羅蜜). And it also refers to the Lotus Sutra's surpassing concept that "Each of the ten realms of living beings mutually contains the other nine" (Jikkai gogu 十界互具). In this sutra of eight fascicles and twenty-eight chapters, there are 69,384 characters; each of them represents the Buddha, and each of the ten realms is endowed with the Buddha. ${ }^{16)}$

On the Chapter 10. "Ichinen sanzen" as Reflected in the Fourteen Chapters of the Latter Half (honmon 本門) of the Lotus Sutra

Numerous great bodhisattvas who had received and accepted the teachings from the original Śākyamuni Buddha in the past emerged from the earth in chapter fifteen of the Lotus Sutra. Maitreya bodhisattva and other eminent bodhisattvas who witnessed that incredible spectacle harbored questions about the relationship between the Buddha and those bodhisattvas. Then, on behalf of the audience, Maitreya directly asked Śakyamuni about bodhisattvas that had emerged from underground. Thereafter, in chapter sixteen, Śākyamuni Buddha declared, "Since I attained Buddhahood, countless kalpas have passed." And he declared that this Sahā world is the pure land of the eternal Buddha. ${ }^{17)}$

On the Chapter 11. Criticisms of Various Schools for Losing Sight of the True Subject of Veneration

The Kegon and Shingon schools establish Vairocana (Ch. Lushena, Jp. Rushana 盧舎 那) and Mahāvairocana (Ch. Dari, Jp. Dainichi 大日) respectively as the true subjects to be revered instead of Śākyamuni Buddha. The Pure Land School cares for Amitābha Bud- 
dha (Ch. Amituo, Jp. Amida 阿弥陀) in the Pure Land Paradise in the west. The eternal Buddha Sākyamuni is the real king of the teachings in this Sahā world. If people do not know of the eternal nature of the Buddha, who is as a father to them, they will know nothing of their obligations. ${ }^{18)}$

\section{On the Chapter 12. "Ichinen sanzen" as a Seed of Buddhahood}

The sutras of the Kegon school and the Shingon school make no mention of the three stages on the way to enlightenment-sowing, nurturing, and harvesting (Shujukudatsu 種熟 脱). Based on the concept of the seed sown in the teachings of the Lotus Sutra, Vasubandhu (Ch. Tianqin, Jp. Tenjin 天親), in his Discourse on the Lotus Sutra (Fahua lun 法華論), asserted that it was an "unsurpassed seed." It later became the "Ichinen sanzen" philosophy of Tiantai. ${ }^{19)}$

\section{On the Chapter 13. Five Holy Proclamations (Three Exhortations; Two Enlightening} Admonitions)

The guardian deities were supposed to have protected Nichiren, but he wasn't protected and met with persecutions. When reflecting on this he thinks of "Five Holy Proclamations" expounded in the Lotus Sutra. In chapter 11, Śākyamuni Buddha calls for propagation of the sutra after his demise three times: (1) He calls for people capable of expounding the sutra to step forth; (2) He expresses his desire to have the Dharma endure; (3) He states how difficult it will be to spread this sutra after his passing. In chapter twelve he encouraged people by (4) assuring the future Buddhahood of Devadatta, and (5) assuring the future Buddhahood of the dragon king's daughter. ${ }^{20)}$

\section{On the Chapter 14. The Bright Mirror Reflecting what was Predicted for the Future}

Nichiren said: “A man called Nichiren was beheaded at two o'clock during the night of the twelfth day in the ninth month last year. His soul has come to Sado Island and in the following year's snowy the second month is writing this work (Kaimoku-shō) to be sent to his closely related disciples." The prophecies in chapter thirteen of persecutions that will be encountered are mirrors reflecting the truth. The persecutions that he experienced are proving the precious words of Śākyamuni Buddha. ${ }^{21)}$

\section{On the Chapter 15. Three Great Vows}

At a young age Nichiren took up Buddha's resolution to save people, and he declared his vow in the Kaimoku-shō. With this vow, invoked as the "Three Great Vows" (Sandai seigan 三大誓願) he resolved to become: “the pillar (hashira 柱) of Japan," "the eyes 
(ganmoku 眼目) of Japan," and "the great ship (taisen 大船) of Japan." ${ }^{22)}$

On the Chapter 16. When Atonement for Wrongdoing is Completed, Emancipation will be Achieved

Looking back on his unwholesome acts far into the past, Nichiren thought that he must have been born as malicious kings and must have persecuted the Lotus Sutra practitioners just as some people of his era in Japan had been destroying the Lotus Sutra's Temples. All of the wrongs he has done have must not yet have been completely atoned for, since he has suffered persecutions after strongly condemning those in Japan who slander the true Dharma. Faithfully conducting himself according to the sutra's teachings, his wrongdoings will be wiped away. ${ }^{23)}$

\section{Part III: Epilogue (Chapters 17-18)}

On the Chapter 17. Means of Propagation: Embrace and Persuade (Shōju 摄受), Refute and Correct (Shakubuku 折伏)

There are two ways of propagation: to embrace and persuade, and to refute and correct. Priority should be given to the method of embracing and persuading when a land is full of evil and ignorant people, as is taught in chapter fourteen. The method of refuting and correcting is preferred when there are many cunning slanderers of the true Dharma, as is taught in chapter twenty. In the age of Mappō, as there are both lands of evil people as well as those of slanderers of the true Dharma, both means of spreading the true Dharma should be present. It is therefore necessary to decide whether Japan today is a land of evil people or a land of slanderers. ${ }^{24)}$

\section{On the Chapter 18. Awareness of the Original Vow of Buddhas}

The persecutions he experienced prove the predictions in the Lotus Sutra that persecutions will take place. Nichiren expresses the happiness of being the actual proof of the truth of this sutra thusly: "My exile is merely a trifle in this present life, which is not lamentable at all. Instead, as I will be rewarded with great happiness in my future life, I feel great joy."25)

1) Shōwa Teihon Nichiren Shōnin Ibun 昭和定本日蓮聖人遺文 (Minobusan Kuonji, 1952), p.535. This paper is a compilation of research during three years of lectures at the Eastern Academy (The Nakamura Hajime Eastern Institute; Maeda Sengaku, President) on the Kaimoku-shō. Texts included: Writings of Nichiren Shōnin Doctrine 2, compiled by Kyōtsū Hori, edited by George Tanabe, Jr. (Honolulu, Hawaii: Nichiren Shū Overseas Propagation Promotion Association, 2002); and Watanabe 
Hōyō, "From the Rissho-ankoku-ron to the Kaimoku-shō, The Issue of the Concept of Spiritual Culture in Nichiren Buddhism," Indogaku Bukkyōgaku kenkyu 印度学仏教学研究 59, no. 3 (2011).

2) Teihon, p.536.

3 ) Teihon, p.538.

4) Teihon, p.538.

5 ) Teihon, p.539.

6) Teihon, p.542.

7 ) Teihon, pp.539-40.

8 ) Teihon, p.541.

9) Teihon, p.542.

10) Teihon, pp.543-5.

11) Teihon, p.546.

12) Teihon, p.546.

13) "Six difficult and nine easy actions (Lotus Sutra, chapter 11)," "Those who destroy Buddhism are those within Buddhism working against Buddhism (Nirvana Sutra, chapter 1)."

14) Teihon, pp.559-60. Chapter $3,10,13,14,20$, etc.

15) Teihon, p.559.

16) Teihon, p.570.

17) Teihon, pp.573-4.

18) Teihon, pp.578-9.

19) Teihon, p.579.

20) Teihon, p.589.

21) Teihon, p.590.

22) Teihon, p.601.

23) Teihon, pp.602-3.

24) Teihon, p.606.

25) Teihon, p.609.

〈Key words〉 Kaimoku-shō, Lotus Sutra, Nichiren

(Associate Member, Institute of Nichiren Buddhism, Risshō University) 